\title{
A Case of Bovine Spongiform Encephalopathy in Denmark
}

Bovine spongiform encephalopathy (BSE), a transmissible spongiform encephalopathy in cattle, was first described in England by Wells et al. (1987). The infection occurs mainly due to digestion of feedstuffs containing ruminant derived protein in form of meat and bone meal contaminated with a scrapie-like agent (Wilesmith et al. 1991). Later, cases of BSE were diagnosed in the Republic of Ireland, Oman, France, and Switzerland (Marinovic \& Senn 1991). This report describes the first case of BSE in Denmark.

In July 1992, a 5-year-old cow of the Scottish Highland breed suspected of BSE was reported to the Danish Veterinary Service according to the Danish Animal Disease Act. The cow, which had been imported from UK in 1988 as a 1-year-old heifer, originated from a Highland breed stock of 9 adult animals and 4 calves. On clinical examination the cow was found to have reduced bodyweight. She was apprehensive, almost constantly gnashing her teeths and salivating. During the last week before euthanization, she developed an aggressive behaviour. Furthermore, she had abnormal gait including hind limb ataxia and incoordination. In several instances she lifted her head high and in periods cutaneous muscular fasciculation could be observed. Hyperaesthesia was not present. The cow had difficulties in both drinking and eating. The owner stated, that the cow progressively had developed clinical symptoms during the last months.
The cow was euthanized by intravenous injection of pentobarbital sodium, the head was removed, and the carcass was buried. At necropsy no macroscopic changes were detected in the brain. Histopathological brain examination was performed after fixation in $10 \%$ buffered neutral formalin, paraffin embedding and haematoxylin-eosin staining.

The histopathological examination showed bilateral symmetrical vacuolization of both grey matter neuropil and neuronal perikarya (Fig. 1 and 2). The vacuolization was mainly present in the brain stem, where it was widely distributed. In the cerebellum and cerebral hemispheres relatively few vacuoles could be observed, however pronounced vacuolization was present in the hippocampus area.

The clinical symptoms and progression of the disease are highly indicative for BSE and similar to those described in other cases (Wells et a1. 1987, Wells \& McGill 1992). Although hyperaesthesia was not present, the symptoms were indicative for BSE, as hyperaesthesia is only present in $75 \%$ of confirmed BSE cases (Wilesmith et al. 1992). The pathological lesions were pathognomonic for spongiform encephalopathy, and identical to those described in other cases of BSE (Wells et al. 1987, Wells $\&$ McGill 1992). Following the confirmation of the diagnosis, the whole herd including a neighbouring flock kept separately but belonging to the same owner-in total 25 cows, bulls, heifers and calves-were transported to the State Veterinary Institute for Virus Re- 


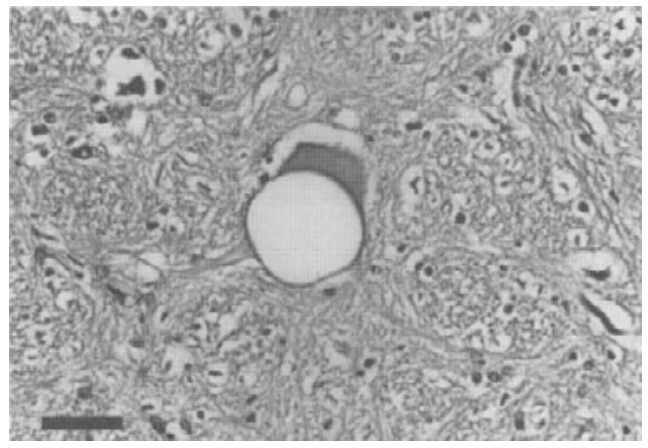

Figure 1. Vacuole in the neuronal perikaryon ("signet ring structure"). Brain stem. Haematoxylin and eosin. Bar $=50 \mu \mathrm{m}$.

search, euthanized and incinerated. Thorough cleaning and disinfection was carried out on the premises and the grazing areas were ploughed.

Based on information from the veterinary authorities in UK, it has been established that the cow prior to exportation had access to meat and bone meal containing ruminant protein. The ban on feeding ruminant protein to ruminants was not introduced in UK until July 1988 , and the exportation took place in June 1988. Moreover, scrapie has never occurred in Denmark, and meat and bone meal has not been imported from UK for many years. Since June 1990 a ban on feeding ruminant protein to ruminants has been in force in Denmark. Therefore, the occurrence of BSE in Denmark is without doubt due to importation of an already infected cow, and the Danish cattle population is still considered free of BSE.

\section{Acknowledgements}

The authors are grateful to Dr. R. Bradley and Dr.G.A.H. Wells, Central Veterinary Laboratory, Weybridge, UK, for confirmation of the diagnosis.

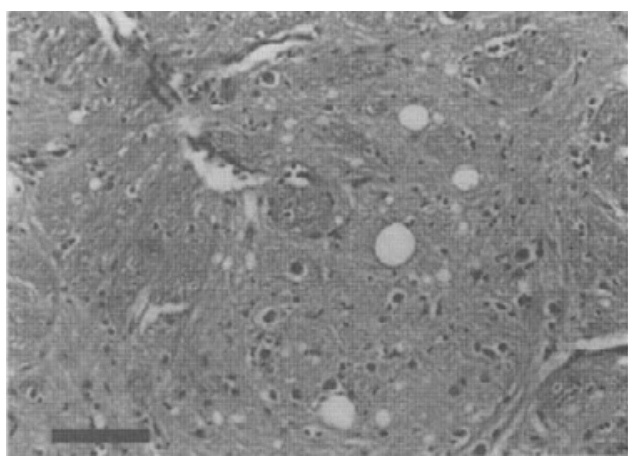

Figure 2. Vacuoles in grey matter neuropil. Brain stem. Haematoxylin and eosin. Bar $=100 \mu \mathrm{m}$.

\section{J.S. Agerholm \\ H.V. Krogh \\ T.K. Nielsen}

National Veterinary Laboratory

Department of Pathology and Epidemiology

Copenhagen, Denmark

\section{S. Ammendrup \\ H. Dalsgaard \\ Danish Veterinary Service \\ Copenhagen, Denmark}

\section{References}

Marinovic Z, Senn B: Die Bovine Spongiforme Enzephalopathie: eine Übersicht (The bovine spongiform encephalopathie: an overview). Schweiz. Arch. Tierheilk. 1991, 133, 349-362.

Wells GAH, McGill IS: Recently described scrapielike encephalopathies of animals: case definitions. Res. Vet. Sci. 1992, 53, 1-10.

Wells GAH, Scott AC, Johnson CT, Gunning RF, Hancock RD, Jeffrey $M$, Dawson $M$, Bradley R: A novel progressive spongiform encephalopathy in cattle. Vet. Rec. 1987, 121, 419-420.

Wilesmith JW, Ryan JBM, Atkinson MJ: Bovine spongiform encephalopathy: epidemiological studies on the origin. Vet. Rec. 1991, 128, 199 203.

Wilesmith JW, Hoinville LJ, Ryan JBM, Sayers AR: Bovine spongiform encephalopathy: aspects of the clinical picture and analyses of possible changes 1986-1990. Vet. Rec. 1992, 130, 197-201.

(Received October 9, 1992; accepted November 17, 1992).

Reprints may be requested from: J.S. Agerholm, National Veterinary Laboratory, Department of Pathology and Epidemiology, Bülowsvej 27, DK-1790 Copenhagen V, Denmark. 